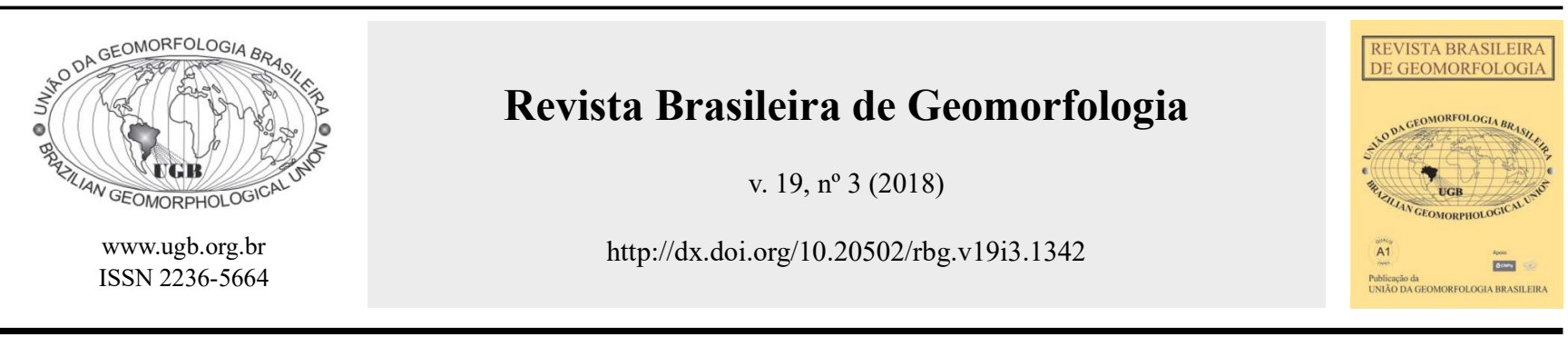

\title{
ANÁLISE E MAPEAMENTO GEOMORFOLÓGICO DA ÁREA DE INFLUÊNCIA DA PLANÍCIE COSTEIRA DE PELOTAS (RIO GRANDE DO SUL, BRASIL)
}

\author{
ANALYSIS AND GEOMORPHOLOGICAL MAPPING OF THE \\ INFLUENCE AREA OF COASTAL PLAIN OF PELOTAS \\ (RIO GRANDE DO SUL, BRAZIL)
}

\author{
Anderson Rodrigo Estevam da Silva \\ Centro de Ciências Humanas e Educação, Universidade Estadual do Paraná \\ Praça Coronel Amazonas, s/n, União da Vitória, Paraná. CEP 84.600-000. Brasil \\ E-mail:aestevam7@gmail.com
}

Moisés Ortemar Rehbein

Instituto de Ciências Humanas, Universidade Federal de Pelotas Rua Cel. Alberto Rosa, 154, Pelotas, Rio Grande do Sul. CEP 96010-770. Brasil

E-mail: moisesgeoufpel@gmail.com

\section{Informações sobre o Artigo}

Data de Recebimento:

27/11/2017

Data de Aprovação:

$29 / 05 / 2018$

Palavras-chave:

Padrões de Formas de Relevo; Tipos de Formas de Relevo; Morfodinâmicas de Planície Costeira.

\section{Keywords:}

Landform Patterns; Landform Types; Morphodynamics of Coastal Plain.

\section{Resumo:}

Este artigo teve como objetivo elaborar e analisar o mapa geomorfológico da área de influência da Planície Costeira de Pelotas, devido à escassez de informações mais detalhadas da Geografia Física do município. Para tanto, obteve-se amparo em orientações metodológicas de Ab'Sáber (1969), União Geográfica Internacional (UGI) (DEMEK et al., 1972), Ross (1992) e Instituto Brasileiro de Geografia e Estatística (IBGE) (2009). O mapeamento adotou a escala 1:125.000 e possibilitou a identificação de fatos geomorfológicos ordenados, quanto à escala de análise, em quatro níveis hierárquicos: $1^{\circ}$ ) morfoestrutura da Bacia de Pelotas; $2^{\circ}$ ) morfoescultura da Planície Costeira; $3^{\circ}$ ) padrões morfológicos de pontal, planícies, dunas, lombadas e terraços; $4^{\circ}$ ) unidades morfocronogenéticas de pontal, planície lacustre, planície paludial, planície alúvio-lacustre, planície alúvio-lagunar do São Gonçalo, planície alúvio-lagunar e planície alúviocoluvionar ( $\sim \mathrm{ka})$; terraço lagunar e terraço alúvio-lagunar ( $120 \mathrm{ka})$; duna costeira, lombada costeira, terraço lagunar e terraço alúvio-coluvionar $(\sim 325$ ka). Sobre as morfodinâmicas verificou-se: oscilações periódicas do lençol freático em superfície; redução da infiltração da água no solo e intensificação do escoamento superficial; suscetibilidade à erosão laminar em solo exposto; alterações de hidrodinâmicas fluvial, lagunar e paludial. De modo principal, os resultados apresentados fornecem auxílio enquanto instrumento à gestão e ao planejamento ambiental, por meio da delimitação de compartimentos do relevo que sinalizam restrições à substituição de coberturas por usos da terra. 


\begin{abstract}
:
This article aimed to elaborate and analyze the geomorphologic map of the influence area of Coastal Plain of Pelotas, due to the lack of information more detailed of physical geography from the municipality. For that, it was obtained the support in methodological orientations of Ab'Sáber (1969), International Geographical Union (IGU) (DEMEK et al., 1972), Ross (1992) and "Instituto Brasileiro de Geografia e Estatística" (IBGE) (2009). The mapping adopted the scale 1:125.000 and provided the identification of ordered geomorphological facts in terms of the analysis scale, in four hierarquy levels: 1st) Morphostructure of Pelotas Basin; 2nd) Morphosculpture of Coastal Plain; 3rd) Morphological patterns of pontal, plains, dunes, lombadas and terraces; 4th) Morphocronogenetic units of pontal, lacustrine plain, paludal plain, fluvio-lacustrine plain, fluvio-lagoon plain of São Gonçalo, fluvio-lagoon plain and fluvio-coluvionar plain $(\sim 5 \mathrm{ka})$; lagoon terrace and fluvio-lagoon terrace $(\sim 120 \mathrm{ka})$; coastal dune, coastal lombada, lagoon terrace and fluvio-coluvionar terrace $(\sim 325 \mathrm{ka})$. About the morphodynamics, it was verified that: periodical oscillations of the water table in surface; decrease of water infiltration in the soil and intensification of surface runoff in the urban area; susceptibility to laminar erosion in exposed soil of the rural area; and changes of fluvial, lagoon and paludal hydrodynamics. Above all, the presented results provide supports as an instrument of management and to the environmental planning, through the delimitation of relief compartments which signals constraints to the covers' substitution for land's using.
\end{abstract}

\section{Introdução}

Na qualidade de instrumento de análise e síntese (ROSS, 2014), a cartografia geomorfológica permite a representação genética das formas de relevo, suas relações com a estrutura e processos, assim como a dinâmica destes processos em suas particularidades (CASSETI, 2015). Nesse sentido, a análise diz respeito a atributos morfogenéticos (processos endógenos e exógenos), morfográficos (formas de relevo), morfométricos (altitude, amplitude altimétrica, declividade, etc.), morfodinâmicos (processos de erosão, deposição, etc., atuais) e morfocronológicos (idade absoluta ou relativa das formas de relevo) (TORRES et al., 2013). Por sua vez, a síntese relaciona-se a uma visão conjunta desses atributos, de maneira que, do mapa geomorfológico, possam resultar diagnósticos ambientais e conhecimento sobre potencialidades e limitações do ambiente à ocupação humana (IBGE, 2009).

Com relação à área de estudo, esta se refere à metade sudeste do município de Pelotas (Figura 1). Situado em parte da Planície Costeira do Rio Grande do Sul (RS) e do Escudo Sul-Rio-Grandense, este município apresenta-se pouco povoado. A maior parcela da sua população está na Planície Costeira, onde o aglomerado urbano atual teve seu prenúncio quando da produção de charque, a partir do fim do século XVIII (MAGALHÃES, 1993). Nesta área, está localizada a terceira cidade mais populosa do RS (IBGE, 2016) e todos modais de transporte de que participa Pelotas (rodoviário, hidroviário, ferroviário e aéreo), além das atividades de agricultura intensiva, pesca e explotação de areia e argila. A história do charque, a paisagem cênica da praia lagunar e a cidade, enquanto polo estudantil e centro do comércio regional, constituem as principais atrações turísticas (PREFEITURA DE PELOTAS, 2013). Todavia, a expansão de atividades humanas nesta parte do território pelotense, mediante, principalmente, intervenções em áreas úmidas, margens fluviais e lagunares e onde se identificam vestígios paleontológicos e arqueológicos, manifesta externalidades do desacerto entre explorar e proteger o patrimônio histórico, cultural e natural.

A partir da consideração deste contexto, o artigo em questão resultou das seguintes constatações:

- A morfologia do relevo condiciona sobremodo a organização do espaço geográfico de Pelotas, de maneira que as alterações socioambientais na Planície Costeira são notadamente maiores do que no Escudo Sul-Rio-Grandense.

- A pequena amplitude altimétrica da Planície Costeira dificulta a distinção de morfologias do relevo e, por conseguinte, a delimitação do condicionamento destas morfologias às dinâmicas fluviais, paludiais e lagunares, as quais sinalizam fragilidades ambientais.

- A falta de um mapa geomorfológico em escala média ou maior prejudica o esclarecimento sobre potencialidades e fragilidades do ambiente, diante à necessidade humana de intervir em dinâmicas ambientais.

- Entre os trabalhos que abordam o modelado costeiro 
de Pelotas destacam-se o de Cunha (1996a), de caráter pedológico, e o de Marth et al. (2008), de ênfase geológica. As demais contribuições provêm do levantamento de atributos do relevo para a análise de bacias hidrográficas.

Sendo assim, o objetivo deste trabalho foi elaborar e analisar o mapa geomorfológico da área de influência da Planície Costeira de Pelotas, cujas dimensões aproximadas são de $720 \mathrm{~km}^{2}, 40 \mathrm{~km}$ de comprimento e $20 \mathrm{~km}$ de largura média. Especificamente, objetivouse: obter dados morfogenéticos e morfocronológicos; representar cartograficamente dados morfológicos; caracterizar alterações morfohidrográficas e analisar morfodinâmicas.

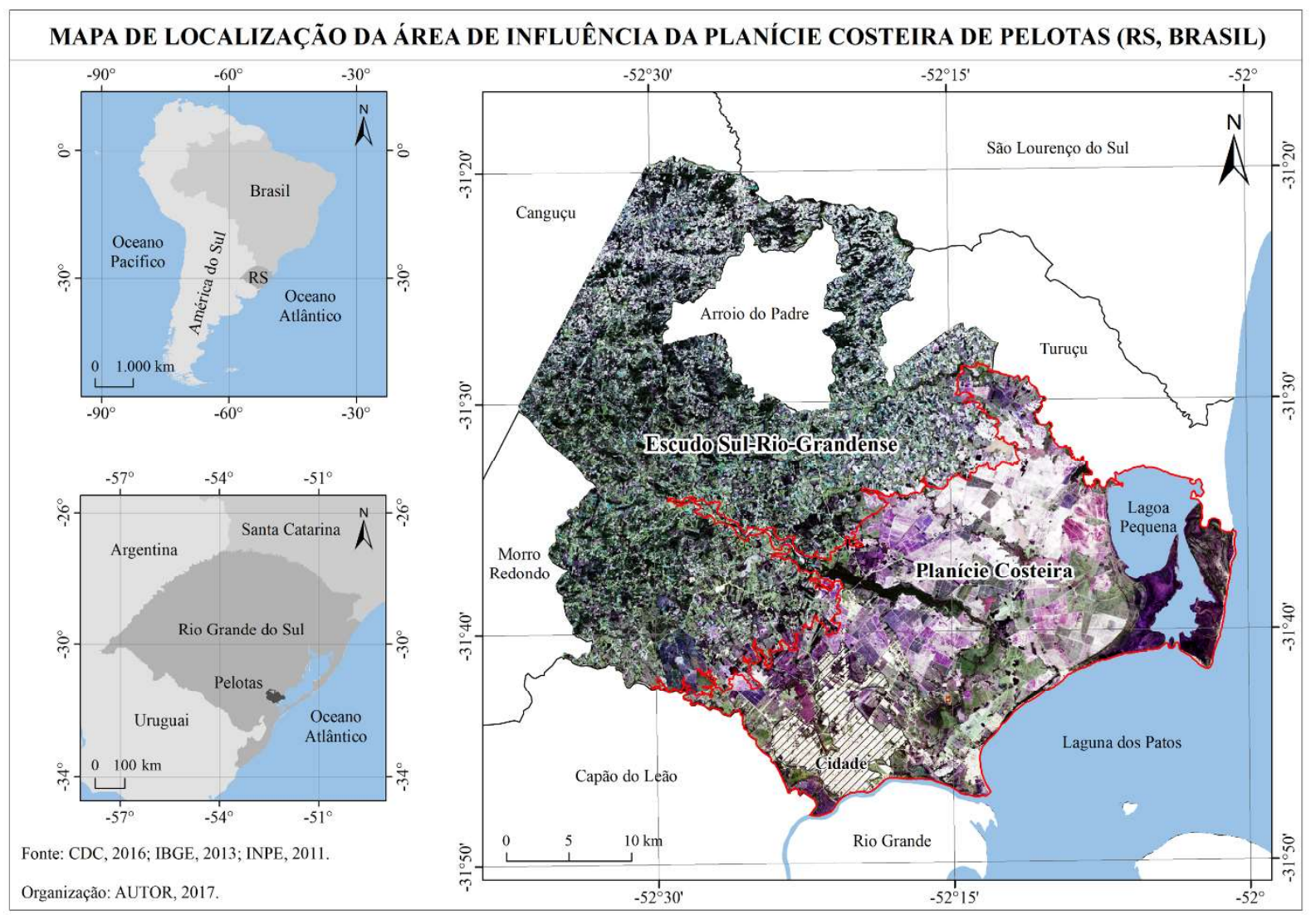

Figura 1-Mapa de localização da área de estudo.

\section{Metodologia}

A metodologia caracterizou-se por quatro etapas, conforme apresentado na Figura 2 e descrito a seguir.

1) Revisão bibliográfica: revisou-se aspectos e processos geológicos, climatológicos, hidrográficos, pedológicos e de usos e coberturas da terra, tendo em vista considerações sobre atributos do relevo. Para tanto, obteve-se amparo em orientações metodológicas de Ab'Sáber (1969), União Geográfica Internacional (UGI) (DEMEK et al., 1972), Ross (1992) e Instituto Brasileiro de Geografia e Estatística (IBGE) (2009). Portanto:

- Em acordo à UGI, buscou-se o entendimento sobre as formas, gênese, idade e dinâmica evolutiva do relevo.

- Ab'Sáber (1969) e Ross (1992) fundamentaram a hierarquização do relevo. Entendeu-se os níveis de compartimentação topográfica e estrutura superficial da paisagem (AB'SÁBER, 1969) correlacionados aos táxons de morfoestrutura, morfoescultura, padrões de formas, tipos de formas e tipos de vertentes (ROSS, 1992); ao passo que o nível de fisiologia da paisagem (AB'SÁBER, 1969) correlacionado aos táxons de tipos de vertentes e formas de processos atuais (ROSS, 1992). Devido à escala de representação do produto final (1:125.000) este estudo não abrangeu os tipos de vertentes. Os processos atuais foram somente mencionados. 
Silva A. R. E. \& Rehbein M. O.

- O IBGE (2009) subsidiou o entendimento e a adaptação de letras-símbolos acerca dos modelados de acumulação.

2) Organização de Banco de Dados Geográficos $(B D G)$ : definiu-se os dados digitais que estruturaram o BDG (Quadro 1).
3) Cartografia e geoprocessamento de base: em ambiente computacional de Sistema de Informações Geográficas, processou-se os materiais do BDG para a geração de Planos de Informação (PIs) referentes a mapas-base, composições coloridas de imagens de satélite e anáglifos de fotografias aéreas.

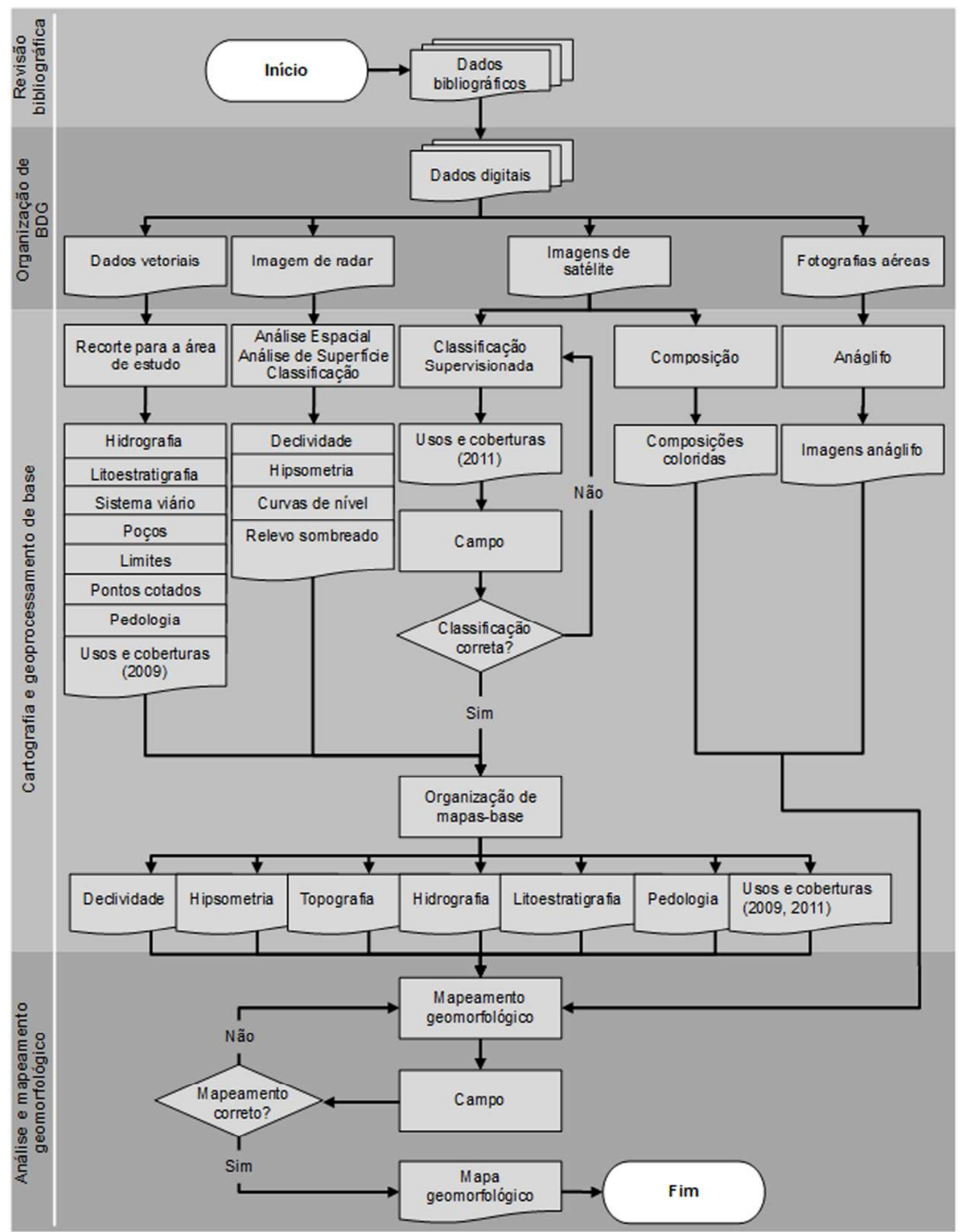

Figura 2 - Fluxograma de procedimentos da pesquisa. 
Quadro 1: BDG.

\begin{tabular}{|c|c|c|c|c|}
\hline Dado digital & $\begin{array}{c}\text { Tipo de } \\
\text { representação }\end{array}$ & $\begin{array}{c}\text { E scala } \\
\text { cartográfica }\end{array}$ & $\begin{array}{c}\text { Resolução } \\
\text { espacial }\end{array}$ & Fonte \\
\hline $\begin{array}{l}\text { Limite da federação; } \\
\text { Limite estadual; } \\
\text { Limite municipal de Pelotas. }\end{array}$ & $\begin{array}{l}\text { Vetorial } \\
\text { (poligono) }\end{array}$ & $1: 250.000$ & - & IB GE (2013) \\
\hline $\begin{array}{l}\text { Curvas de nivel ( } 20 \mathrm{~m}) \\
\text { Pontos cotados (metros); } \\
\text { Hidrografia (cursos fluviais e } \\
\text { corpos d'água); } \\
\text { Sistema viário. }\end{array}$ & $\begin{array}{l}\text { Vetorial } \\
\text { (linha e } \\
\text { poligono) }\end{array}$ & $1: 50.000$ & - & $\begin{array}{c}\text { Hasenack e } \\
\text { Weber (2010) }\end{array}$ \\
\hline Mapa Geológico do R S* & $\begin{array}{c}\text { Vetorial } \\
\text { (poligono) }\end{array}$ & $1: 750.000$ & - & CPRM (2008) \\
\hline Mapa Pedológico de Pelotas** & Matricial & $1: 100.000$ & - & Cunha (1996b) \\
\hline $\begin{array}{l}\text { Mapa da cobertura vegetal do } \\
\text { Bioma Pampa }\end{array}$ & $\begin{array}{c}\text { Vetorial } \\
\text { (poligono) }\end{array}$ & $1: 250.000$ & - & UFRGS (2009) \\
\hline Cadastro de poços & $\begin{array}{l}\text { Vetorial } \\
\text { (ponto) }\end{array}$ & - & - & CPRM (2016) \\
\hline Imagem de radar SRTM & Matricial & - & $\sim 30 \mathrm{~m}$ & INPE (2016) \\
\hline $\begin{array}{l}\text { Imagem de satélite Landsat } 5 \\
\mathrm{TM}(\text { Bandas } 3,4 \text { e } 5)\end{array}$ & Matricial & - & $\sim 30 \mathrm{~m}$ & $\begin{array}{l}\text { INPE (1985; } \\
1986 ; 2000 ; \\
2011)\end{array}$ \\
\hline $\begin{array}{l}\text { Fotografias aéreas digitalizadas } \\
\text { (Voo SH-22-T - Faixas de voo } \\
8,9,10,11,12,13,13 \mathrm{~A}, 14 \text { ) }\end{array}$ & Matricial & $1: 40.000$ & - & AL M (1953) \\
\hline
\end{tabular}

*No contexto da área de estudo, este mapa teve como base as cartas geológicas atualizadas por Favilla et al. (2000) na escala 1:250.000.

4) Análise e mapeamento geomorfológico: sobrepôs-se os PIs resultantes do processamento de materiais do BDG para que fossem analisadas informações sobre atributos do relevo. Para isso, fez-se a seleção de PIs referentes à morfologia (morfografia e morfometria), morfocronogênese (morfocronologia e morfogênese) e morfodinâmica, como explicado a seguir.

Morfologia: destacaram-se os PIs de curvas de nível (com equidistância de $1 \mathrm{~m}$ ), clinografia e hipsometria extraídos de imagem de radar. Estes dados auxiliaram o mapeamento de rupturas de declive mediante a análise visual da rugosidade topográfica e da área de influência de corpos d'água. Esta influência foi analisada em composições coloridas de imagens de satélite (obtidas em datas posteriores aos maiores índices pluviométricos) e em anáglifos de fotografias aéreas. Da análise morfológica resultou o mapa de padrões de formas do relevo.

Morfocronogênese: as informações de topografia, hipsometria, clinografia, anáglifos de fotografias aéreas e imagens de satélite (composições coloridas), em conjunto a informações de litoestratigrafias e solos, auxiliaram a delimitação de tipos de formas do relevo. A descontinuidade espacial de elementos de litologia, pedologia e vegetação foi fundamental para a identificação de feições do relevo sem variação de aclive entre si.

Morfodinâmica: sobrepôs-se os usos e coberturas da terra aos tipos de formas de relevo. Simultaneamente, anáglifos de fotografias aéreas e imagens de satélite (composições coloridas) auxiliaram a identificação de feições resultantes de processos geomorfológicos ativos. Na sequência, foi-se a campo (nas datas de 29/10/2015, 10/10/2016 e 11/10/2016) para validar as informações mapeadas. 
De posse da informação geomorfológica levantada e analisada, procedeu-se com a organização cartográfica final, como síntese do que foi estudado.

\section{Geomorfologia da área de influência da Planície Costeira de Pelotas}

Os glácio-eustatismos quaternários constituem elemento importante na modelagem de planícies costeiras da superfície terrestre, com a definição de barreiras arenosas que registram picos altimétricos de transgressões marinhas (DILLENBURG; HESP, 2009). Inserida nessa dinâmica, a área de estudo está composta por sedimentos que conformam parte da fisiografia superficial da Bacia de Pelotas (BARBOZA et al., 2008), enquanto resultado da progradação-retrogradação do litoral meridional brasileiro (TESSLER; GOYA, 2005), simultânea à denudação do Escudo Sul-Rio-
Grandense (DUTRA, 2016). Nessa conjuntura, devido ao retrabalhamento flúvio-marinho, caracterizam-se rupturas de declive suaves e descontinuidades litopedológicas que compartimentam um relevo afeiçoado majoritariamente em unidades (padrões) de terraços, dunas e planícies, como indicado em Rosa (1985), Cunha (1996b), Cunha e Silveira (1996), Tomazelli e Villwock (2000) e IBGE (2003). A articulação desse arcabouço geológico-geomorfológico com o clima subtropical úmido atual acentua processos pedogenéticos e biogeográficos que permitem uma biodiversidade abundante, definida pelo encontro dos biomas Mata Atlântica e Pampa (PREFEITURA DE PELOTAS, 2013).

$\mathrm{Na}$ Figura 3, tem-se o mapa geomorfológico da área de influência da Planície Costeira de Pelotas e, no Quadro 2, a respectiva síntese da representação. A análise geomorfológica é apresentada a seguir.

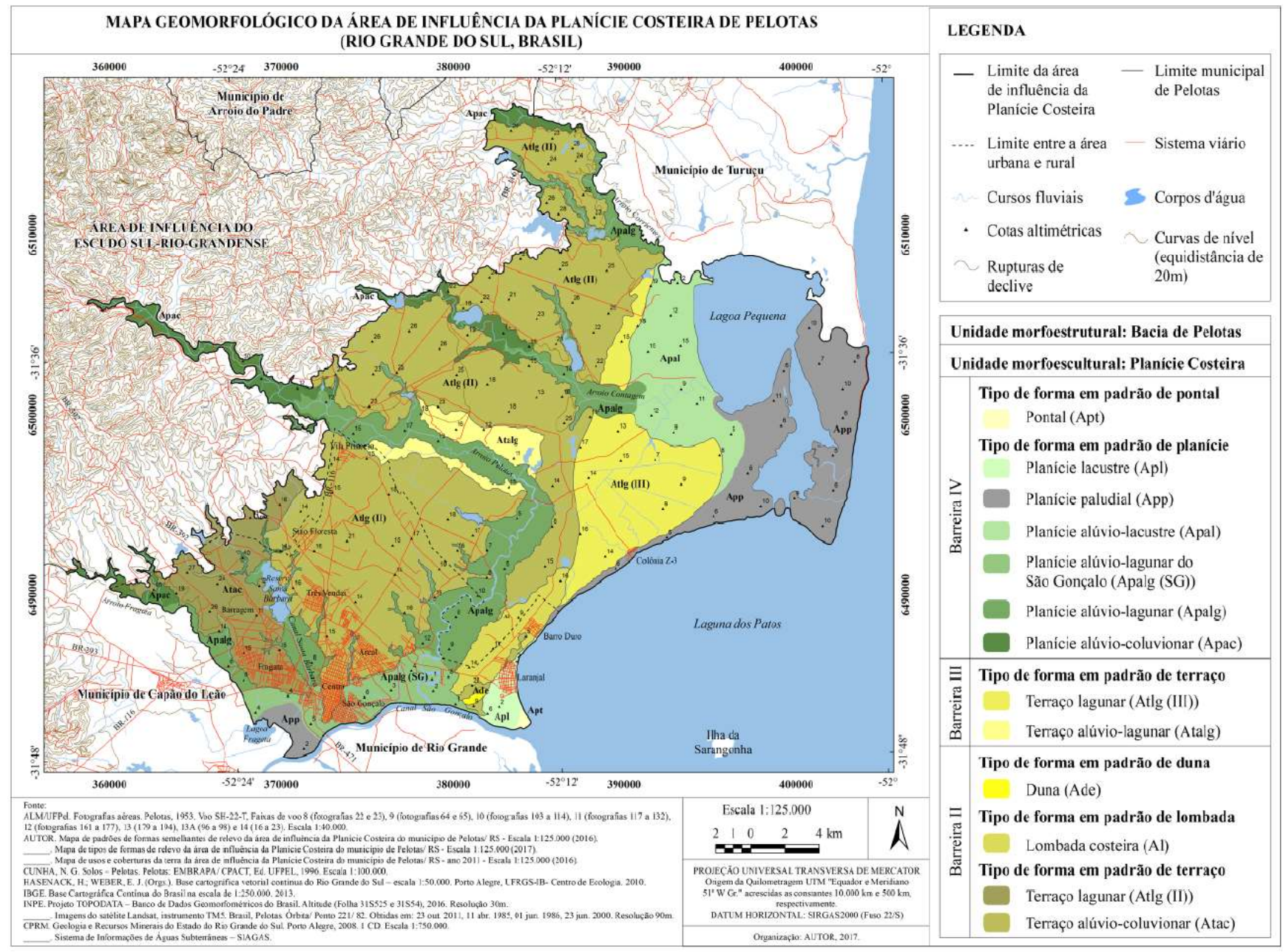

Figura 3 - Mapa geomorfológico da área de influência da Planície Costeira de Pelotas. 
Análise e Mapeamento Geomorfológico da Área de Influência da Planície Costeira de Pelotas

Quadro 2: Síntese dos atributos do relevo da área de influência da Planície Costeira de Pelotas.

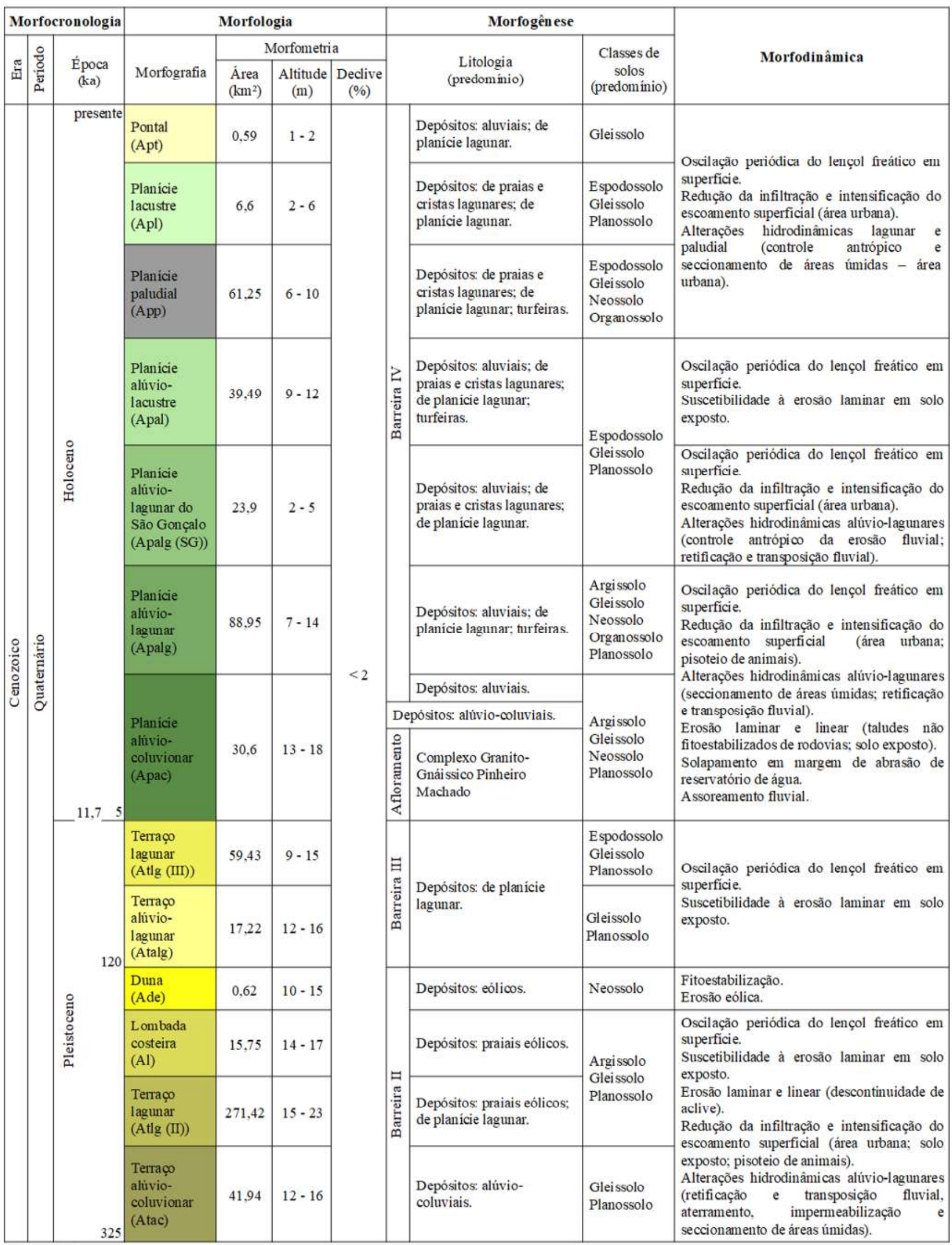




\section{Unidade Morfoestrutural}

\section{Bacia de Pelotas}

A Bacia de Pelotas está localizada no extremo sul da Margem Continental Brasileira e nordeste da Margem Continental Uruguaia (BARBOZA et al., 2011). Limita-se em sua porção norte, com a Bacia de Santos, no Alto de Florianópolis (DIAS et al., 1994), ao passo que no sul, com a Bacia de Punta Del Este, no Alto de Polônio, no Uruguai (URIEN; MARTINS, 1978 apud BARBOZA et al., 2011)

A gênese da Bacia de Pelotas está atrelada à abertura do oceano Atlântico Sul, em virtude de esforços extensionais do continente Gondwana, quando da separação entre a América do Sul e a África há aproximadamente $65 \mathrm{Ma}$ (MENEGAT et al., 1998). Por consequência, o embasamento dessa Bacia refere-se a rochas granítico-gnáissicas pré-cambrianas (DIAS et al., 1994). A oeste da área de estudo, esse embasamento é aflorante e conforma a morfoescultura do Escudo SulRio-Grandense, na Província Mantiqueira (WILDNER; LOPES, 2010).

Após a abertura do oceano Atlântico, culminou o condicionamento para a evolução da Província Costeira (MENEGAT et al., 1998). Nesta Província, a área de estudo forma parte da Planície Costeira Interna Gaúcha (IBGE, 2003).

\section{Unidade Morfoescultural}

\section{Planície Costeira}

Conforme Tomazelli e Villwock (2000), existem vários estudos que apontam a ocorrência de um amplo sistema de leques aluviais somados ao acréscimo lateral de quatro sistemas de deposição do tipo "LagunaBarreira", importantes para a formação da Planície Costeira Gaúcha.

O sistema de leques aluviais decorre da agradação de sedimentos por meio de processos exógenos à borda de terras altas do Escudo Sul-Rio-Grandense, adjacentes à Planície Costeira (TOMAZELLI; VILLWOCK, 2000). Na parte mais proximal dessas terras, há a predominância de sedimentos de granulometria grosseira resultantes de transporte gravitacional (elúvios e colúvios decorrentes da alteração sofrida pelas rochas granítico-gnáissicas), que graduam quanto mais próximos à porção distal dos leques, sendo aí, então, transportados e depositados em meio aquoso a partir de fluxos canalizados e não-canalizados (TOMAZELLI; VILLWOCK, 2000).

Durante o Mioceno superior, a evolução desse sistema de leques dava-se por meio da interdigitação das fácies com o mar - atuavam como se fossem deltas. No Quaternário, com a colmatação iniciada no complexo Patos-Mirim essas fácies passaram a estar submetidas ao regime hidrodinâmico lagunar. Tem-se como resultado deste processo de retrabalhamento o desenvolvimento de terraços, escalonados ao longo do aclive dos leques, como evidências das variações de nível das lagunas, em função da oscilação do nível relativo do mar no Quaternário (TOMAZELLI; VILLWOCK, 2000).

Os sistemas laguna-barreira desenvolveram-se lateralmente a leste do Escudo Sul-Rio-Grandense e marcam o máximo de uma transgressão, seguida de uma regressão marinha (TOMAZELLI; VILLWOCK, 2000). A seguir, são descritos os três sistemas identificados na área de estudo com base em Tomazelli e Villwock (2000) e CPRM (2008; 2016).

Sistema II: seu pico pode ser associado ao estágio isotópico de oxigênio 9, o que lhe admite uma idade de cerca de 325 ka (TOMAZELLI; VILLWOCK, 2000).

Este sistema corresponde ao primeiro estágio na evolução da "Barreira Múltipla Complexa" descrita por Villwock (1977, 1984), cuja individualização foi responsável pelo isolamento de um gigantesco corpo lagunar representado, hoje em dia, pela Lagoa dos Patos [(topônimo de Laguna dos Patos)] e pela Lagoa Mirim e que esse autor denominou de "Sistema Lagunar Patos-Mirim" (TOMAZELLI; VILLWOCK, 2000, p.389).

Sistema III: encontra-se preservado e foi responsável pelo estabelecimento do Sistema Lagunar Patos-Mirim, sendo, portanto, fundamental à formação destes corpos lagunares e à evolução da Planície Costeira (TOMAZELLI; VILLWOCK, 2000). Aos depósitos deste sistema atribui-se uma idade de aproximadamente $120 \mathrm{ka}$ (MARTINS et al., 1982 apud TOMAZELLI; VILLWOCK, 2000).

O Sistema Lagunar III envolveu um complexo de ambientes deposicionais instalados na região de retrobarreira. Os depósitos ali acumulados são representados principalmente por areias finas, síltico-argilosas, pobremente 
selecionadas, de coloração creme, com laminação plano-paralela e, frequentemente, incluindo concreções carbonáticas e ferruginosas (TOMAZELLI; VILLWOCK, 2000, p.390-392).

Sistema IV: está associado ao estágio isotópico de oxigênio 1, equivalente a 5 ka (TOMAZELLI; VILLWOCK, 2000).

Deste sistema decorre a formação de corpos lagunares característicos da Planície Costeira gaúcha como a Lagoa Mangueira, Lagoa do Peixe e o rosário de lagoas do litoral norte do Estado. Esse sistema constitui ambientes deposicionais diversos como:

corpos aquosos costeiros (lagos, lagoas $e$ lagunas), sistemas aluviais (rios meandrantes e canais interlagunares), sistemas deltaicos (deltas flúvio-lagunares e deltas de "maré lagunar") e sistemas paludiais (pântanos, alagadiços e turfeiras.) (TOMAZELLI; VILLWOCK, 2000, p.393).

\section{Tipo de forma em padrão de pontal}

A forma de pontal é conhecida pelo topônimo de Pontal da Barra. Correlaciona-se ao que Cunha e Silveira (1996) definem como Banhados Marginais da Lagoa dos Patos e, por conseguinte, é pedologicamente semelhante à planície paludial. Desse modo, o solo dominante é o Gleissolo, muito mal drenado. No geral, seu material de origem diz respeito a argilas e areias da formação Aluvião Lagunar (CUNHA; SILVEIRA, 1996).

A má drenagem decorre da baixa declividade e altitude que impedem o fluxo da água por gravidade. A ocorrência de aluviões na borda convexa do pontal permite especular o aumento do aporte de sedimentos fluviais atrelado ao aprofundamento de canais iniciado com a regressão marinha no Holoceno. Além de contribuírem para a colmatagem do Sistema PatosMirim (SIMON, 2007) e a formação de planícies alúviolagunares e paludiais, esses sedimentos podem ter sido transportados em suspensão pelo Canal São Gonçalo e depositados junto a outros de origem lagunar que compõem o pontal (Figura 4).

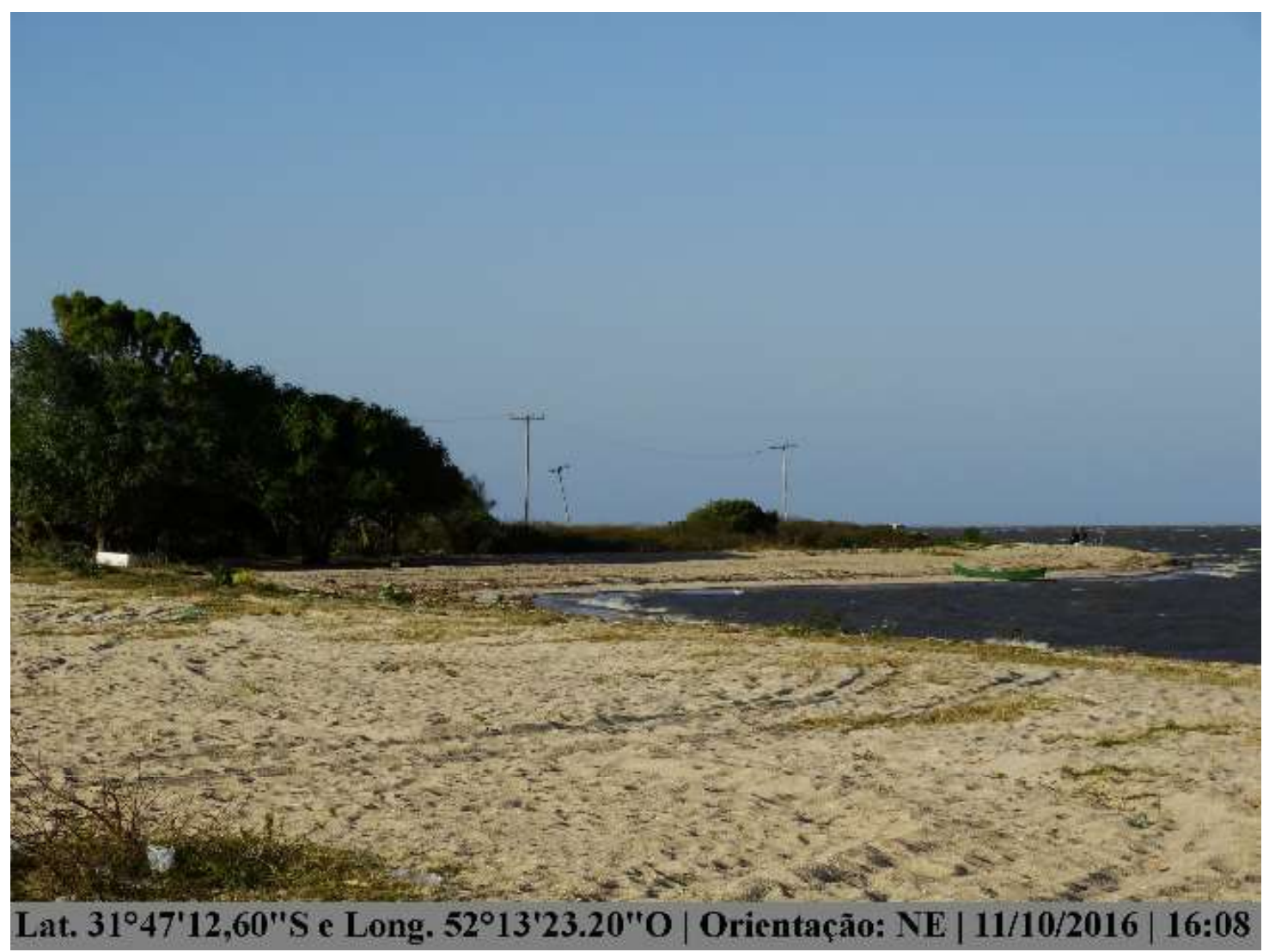

Figura 4 - Pontal, no Pontal da Barra - Laranjal. 


\section{Tipo de forma em padrão de planície}

\section{Planície lacustre}

Apresenta semelhanças ao que Cunha (1996a) identifica como Traços de Praia Lacustres. Apesar da proximidade ao Canal São Gonçalo e à Laguna dos Patos, não se trata de um ambiente paludial. No inverno, essa planície encontra-se saturada por água em superfície, mas bem drenada no verão (CUNHA; SILVEIRA, 1996). Nas partes altas predomina o Espodossolo, profundo, de moderadamente bem a mal drenado, o que supõe a diminuição da permeabilidade em razão do aumento do teor de argila no subsolo; nas partes baixas, predomina o Gleissolo, muito mal drenado (CUNHA; SILVEIRA, 1996).

Em acordo a Tomazelli e Villwock (2000), a insignificante carga de sedimentos fluviais, apontada por Cunha e Silveira (1996), deveu-se à estabilização temporária no final do evento transgressivo, que promoveu a retenção da carga arenosa dos rios em corpos lagunares (Laguna dos Patos e Lagoa Mirim) localizados na retrobarreira de barramentos pleistocênicos. Estes autores também esclarecem que, em virtude do pouco suprimento de aluviões, seja provável que a progradação da Barreira IV tenha ocorrido pelo fornecimento de areias de antepraia.

\section{Planície paludial}

A planície paludial encontra-se descontinuada em duas zonas geomorfológicas indicadas por Cunha e Silveira (1996) como Banhados Lacustres Baixos e Banhados Marginais da Lagoa dos Patos.

Desse modo, depreende-se que a evolução da planície paludial tenha ocorrido quando da progradação da Barreira IV, que permitiu a emersão parcial de terrenos às margens de corpos d'água lagunares e fluviais. Além disso, pode-se deduzir que, conforme Corrêa et al. (2015), a formação da turfa tenha ocorrido com a elevação repentina da água por subsidência da área. A campo o que se verifica é que a formação da turfa está vinculada à oscilação periódica do lençol freático, quando de cheias de corpos d'água fluviais e lagunares, o que permite o predomínio de plantas melhor adaptadas ao meio aquático.

\section{Planície alúvio-lacustre}

Com base em Cunha (1996a, 1996b), Cunha e Silveira (1996) e no que se observa a campo, deduz-se que a planície alúvio-lacustre resulte da simultânea progradação da Barreira IV e deposição de alúvios oriundos dos Arroios Contagem e Corrientes que hoje desaguam na Lagoa Pequena. Há que se considerar que o acréscimo de alúvios na referida planície supõe o reajuste basal realizado por estes cursos fluviais a fim de equilibrarem-se quanto a seus processos, haja vista referência feita por Tomazelli e Villwock (2000) sobre uma estabilização temporária (highstand) no final do evento transgressivo holocênico.

Intui-se que ao acompanhar o decréscimo altimétrico do relevo, o recuo gradual da água do mar definia lagos influenciados por um lençol freático ainda alto e evidenciava superfícies relativamente mais altas que as adjacentes a leste. Com efeito, é possível verificar que embora a planície alúvio-lacustre apresente turfeiras, a sua gênese não é intrínseca à oscilação do lençol freático tal como ocorre em partes baixas do ambiente paludial que circunda a Lagoa Pequena na atualidade. Além disso, observa-se que o terraço lagunar da Barreira III, associado ao pico do mar no Holoceno, condicionou os limites da planície alúvio-lacustre, que se coalesceu à planície alúvio-lagunar dos Arroios Contagem e Corrientes.

\section{Planície alúvio-lagunar do São Gonçalo}

Com base em Tomazelli e Villwock (2000) e Simon (2007), a evolução dessa planície está atribuída à colmatagem da Lagoa Mirim devido à deposição sedimentar efetivada pelo restabelecimento do Sistema Lagunar Patos-Mirim e pela dinâmica fluvial de cursos com foz no Canal São Gonçalo. Para a identificação dessa descontinuidade entre a planície alúvio-lagunar e a alúvio-lagunar do São Gonçalo os mapeamentos de Cunha (1996a, 1996b) foram fundamentais.

\section{Planície alúvio-lagunar}

A fase regressiva marinha anterior ao último pico transgressivo (Barreira IV), segundo Tomazelli e Villwock (2000), estabeleceu um desnível do mar de aproximadamente $120 \mathrm{~m}$ (há $17 \mathrm{ka}$ ) em relação ao nível atual. Sendo assim, é provável que os cursos d'água tenham aprofundado consideravelmente seus 


\section{Análise e Mapeamento Geomorfológico da Área de Influência da Planície Costeira de Pelotas}

canais a fim de equilibrarem suas taxas de erosão, transporte e deposição antes de serem invadidos novamente pela água e sedimentos do mar e dos corpos lagunares (restabelecimento do Sistema Lagunar PatosMirim) no Holoceno.

Dessa maneira, com fundamento em Tomazelli e Villwock (2000), deduz-se que, na formação da Barreira IV, houve intenso retrabalho de sedimentos para o estabelecimento das planícies alúvio-lagunares mediante o avanço e recuo marinho por entre as áreas de terraço lagunar das Barreiras II e III. Salienta-se que o nível do mar alcançou em torno de 4 a $5 \mathrm{~m}$ acima do nível atual na última transgressão(TOMAZELLI; VILLWOCK, 2000). À planície alúvio-lagunar são correlatas as zonas de Terras com Matas Fluviais, Planície Baixa Lacustre e Banhados Fluviais indicadas por Cunha e Silveira (1996) (Figura 5).

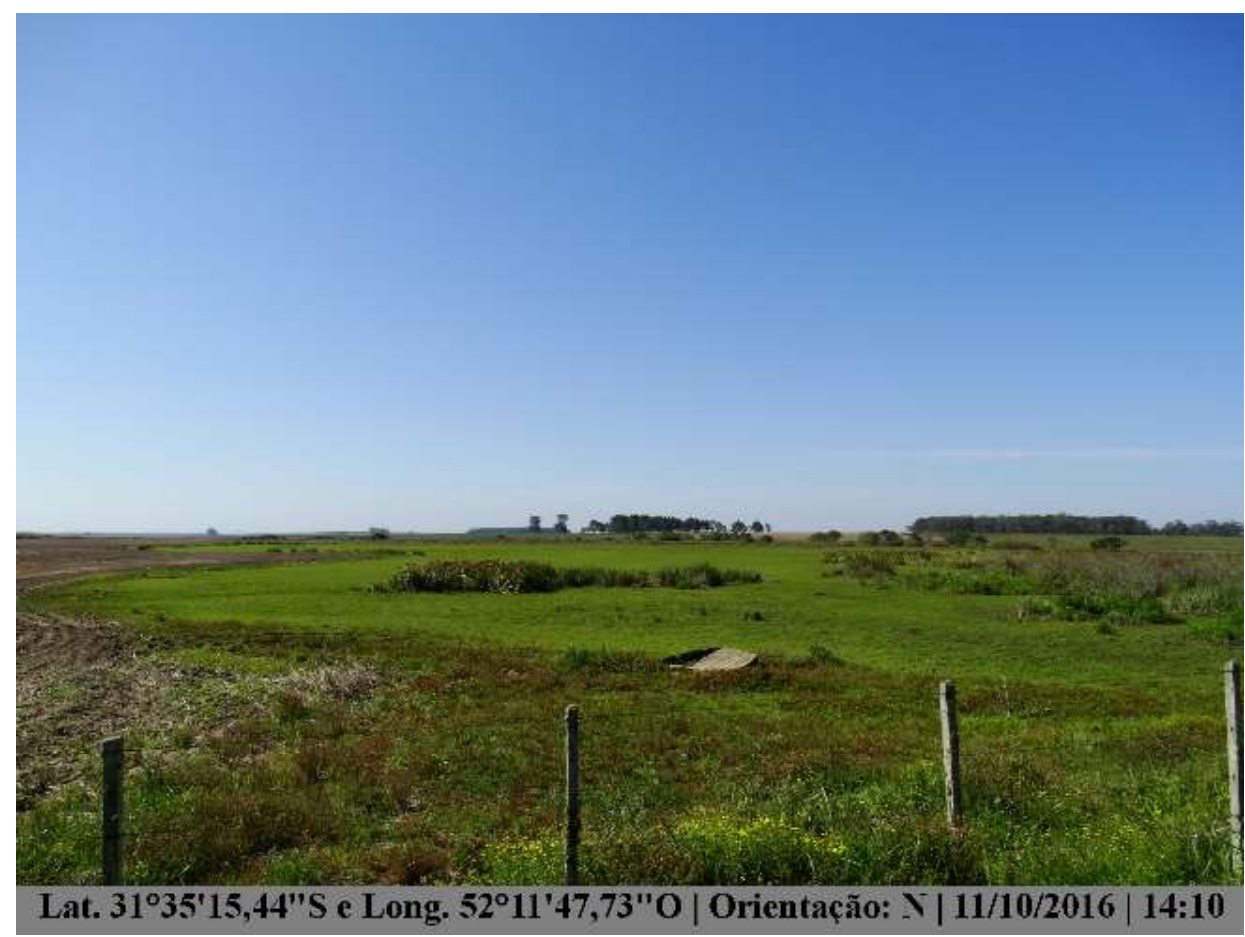

Figura 5-Planície alúvio-lagunar de afluente do Arroio Contagem.

\section{Planície alúvio-coluvionar}

Em sua maior parte, as planícies alúvio-coluvionares são correlacionáveis às Terras Baixas Fluviais indicadas por Cunha e Silveira (1996). Entende-se que a situação espacial deste tipo de forma seja consequência da drenagem atual entalhada em zonas friáveis da estrutura do Escudo Sul-Rio-Grandense, constituindo o que Tomazelli e Villwock (2000) caracterizam como leques aluviais coalescentes datados do final do Terciário. Entretanto, haja vista o retrabalho sofrido por esses leques com a formação dos barramentos lagunares e os eustatismos negativos que potencializaram a erosão regressiva, entende-se que os aluviões observáveis hoje sejam recentes, conforme apontam Cunha e Silveira (1996) e CPRM (2008). Os colúvios em associação aos alúvios são característicos desse tipo de forma por conta da declividade das vertentes, que caracterizam os vales da estrutura cristalina aflorante.

Desse modo, compreende-se que a origem relativa das planícies alúvio-coluvionares seja antecedente à das planícies alúvio-lagunares, pois as segundas constituem o prolongamento das primeiras no que se refere ao gradiente fluvial e à progradação de barreiras lagunares.

\section{Tipo de forma em padrão de duna}

As dunas estão esculpidas sobre os depósitos mais recentes que constituem a Barreira II. Em função de suas areias quartzosas distróficas (da classe dos Neossolos) serem relativas ao Pleistoceno (CUNHA; SILVEIRA, 1996), essas formas são entendidas por Rosa (1985) como dunas fósseis originadas pelo vento e que indicam a ocorrência pretérita de um clima mais seco. De acordo com este autor, as formas de duna dizem respeito à formação Itapoã. 
Tendo como parâmetro o decréscimo da altitude alcançada pelas transgressões marinhas, apresentadas em Tomazelli e Villwock (2000) e CPRM (2008), o que se entende é que os materiais dessas dunas tenham sido retrabalhados pelo vento após a regressão marinha que definiu a Barreira II. Com base na altimetria, também se depreende que esses depósitos tenham sofrido algum retrabalhamento quando da atuação do Sistema III, pois se observa altitudes semelhantes para as dunas $(10-15$ m) e os terraços alúvio-lagunares da Barreira III (12 $16 \mathrm{~m}$ ), os quais são ainda mais interiorizados do que as dunas na área de estudo (Figura 6).

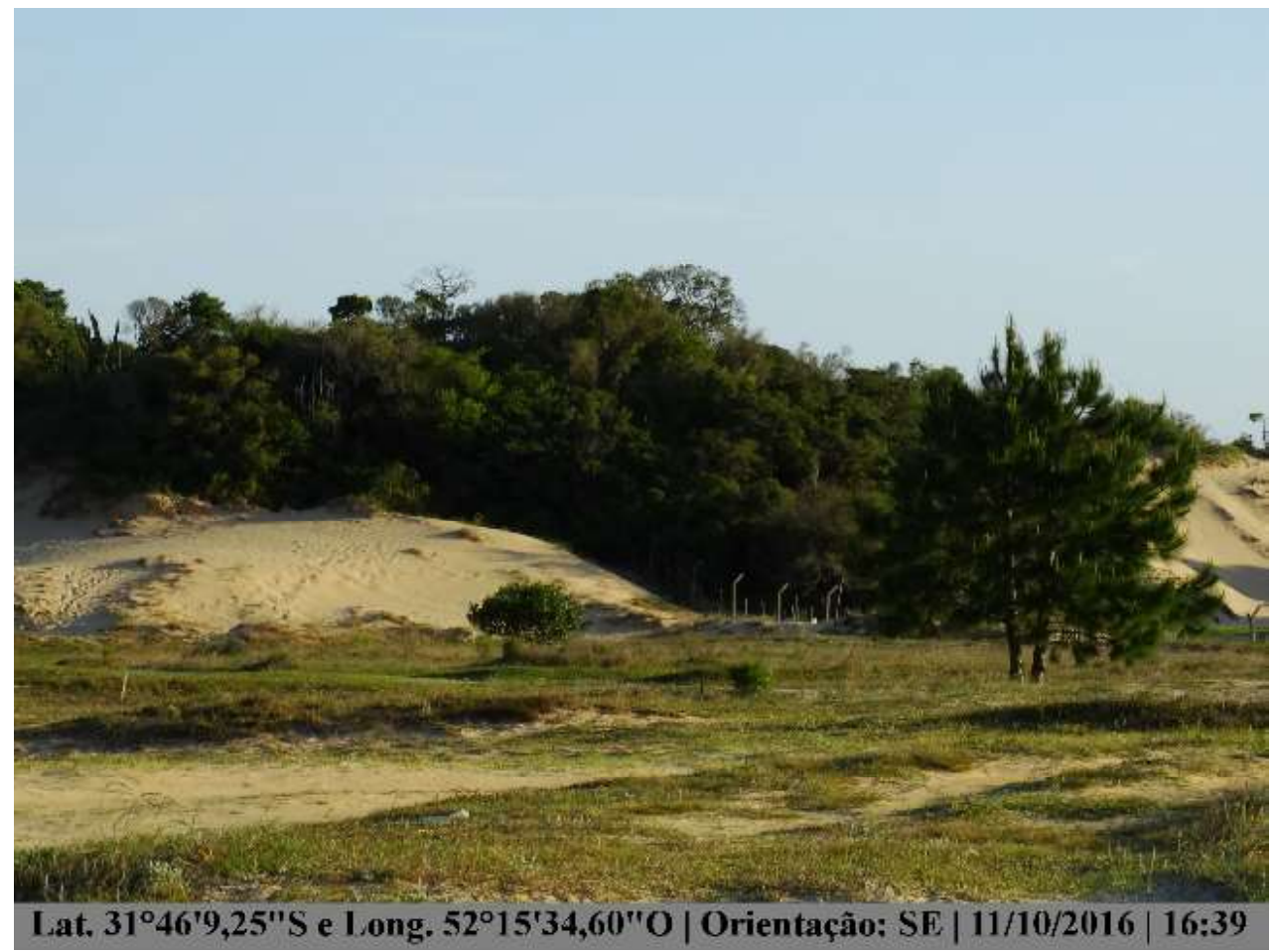

Figura 6 - Dunas, no Laranjal, a cerca de $50 \mathrm{~km}$ da atual linha de costa marinha.

\section{Tipo de forma em padrão de lombada}

Com apoio em CPRM (2008; 2016), o que se especula enquanto a gênese das lombadas é que essas tenham tido seu princípio evolutivo na definição de uma linha de costa durante o Pleistoceno, haja vista a prevalência de sua litologia - de depósitos praiais eólicos - de modo adelgaçado ao longo de todo o comprimento da área de estudo, no sentido SSE-NNE. Essa localização praticamente divide a área de estudo quase ao meio, definindo de um lado o predomínio do pacote sedimentar da Barreira II e de outro o predomínio dos depósitos da Barreira III e IV.

Atualmente, na parte oeste das lombadas, o que se observa é que a incisão fluvial, iniciada com a alteração do nível de base após o pico de há $\sim 325$ ka e acentuada por outros dois eventos transgressivoregressivos marinhos, definiu com certa nitidez uma descontinuidade de aclive entre esta área relativamente alta e a área deprimida das planícies do Arroio Pelotas e do Canal São Gonçalo. Na parte leste das lombadas, a descontinuidade da topografia em relação à planície lacustre sugere a ação erosiva lagunar durante a evolução da Laguna dos Patos, pois, até mesmo hoje, são observados avanços desse corpo d'água - em associação ao Canal São Gonçalo - nessa planície em virtude da ocasional mudança na direção dos ventos (Figura 7).

\section{Tipo de forma em padrão de terraço}

\section{Terraço lagunar (Barreira III)}

É correlato ao que Tomazelli e Villwock (2000) constatam como terraço de abrasão e ao que Cunha e Silveira (1996) indicam como Planície Média.

[...] à semelhança do que ocorreu com o Sistema Lagunar II, a transgressão rápida das águas lagunares foi responsável pela 


\section{Análise e Mapeamento Geomorfológico da Área de Influência da Planície Costeira de Pelotas}

elaboração de um terraço de abrasão (superficie transgressiva) nos depósitos do Sistema de Leques Aluviais, posicionado entre 8-15 $m$ de altitude (TOMAZELLI; VILLWOCK, 2000, p.392).

Segundo Tomazelli e Villwock (2000), as concreções carbonáticas comumente ocorrem na região meridional da Planície Costeira Gaúcha, entre os municípios de Rio Grande e Chuí, e formam um calcrete pedogenético ao se concentrarem no horizonte $\mathrm{B}$ dos solos, do que resulta um importante indicador paleoclimático de fases áridas. Conforme Cunha e Silveira (1996), não são identificáveis tais concreções em Pelotas. No entanto, tida em conta a proximidade de Rio Grande a Pelotas e a abrangência da atuação de centros atmosféricos, independentemente da ocorrência de concreções carbonáticas, confirma-se o mesmo indício paleoclimático para a área de estudo.

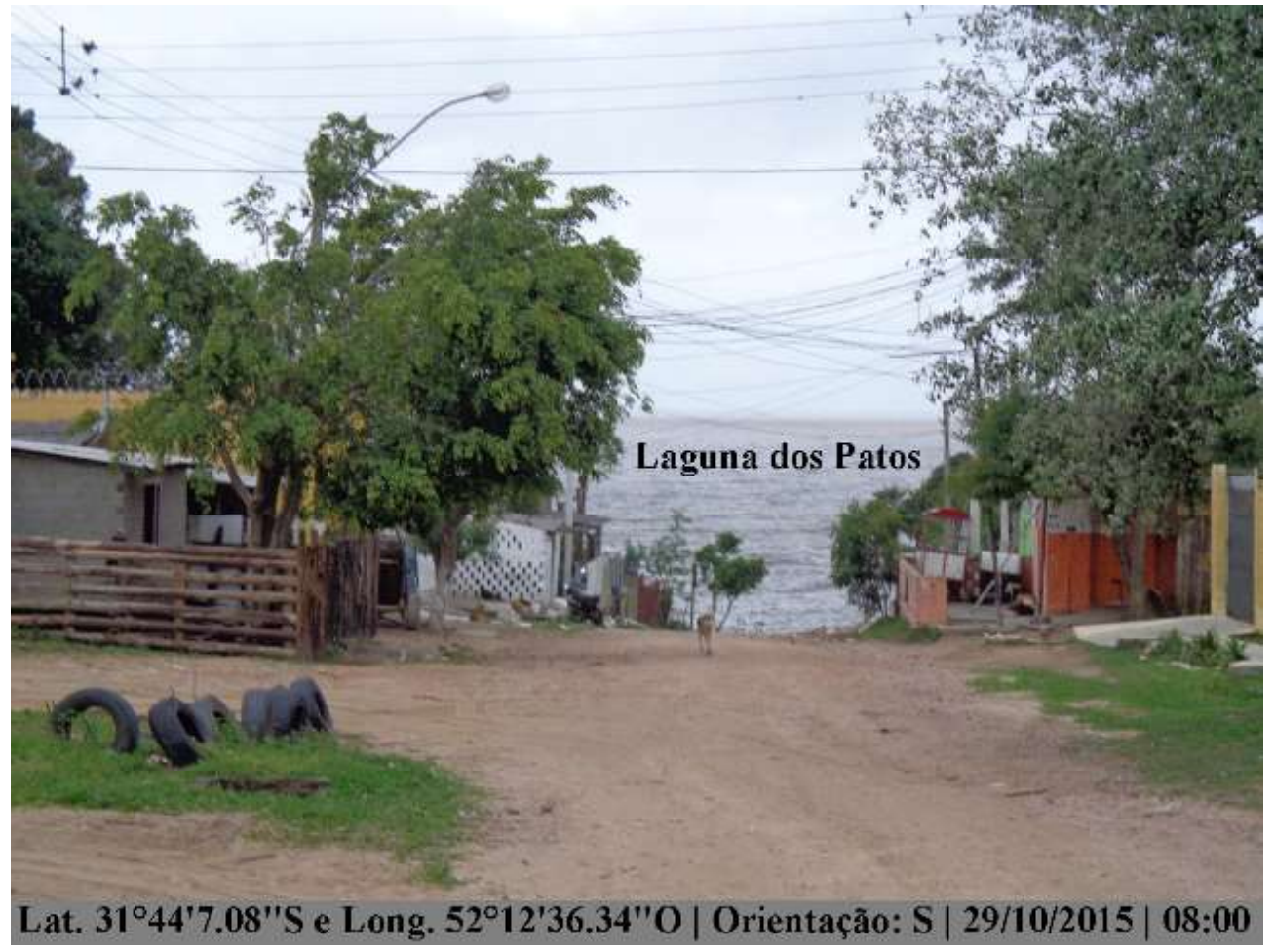

Figura 7 - Lombada costeira ( $1^{\circ}$ Plano) e sua ruptura de declive com a forma de planície lacustre às margens da Laguna dos Patos $\left(2^{\circ}\right.$ Plano), próximo à Av. Mato Grosso, no Barro Duro - Laranjal.

Com base em Cunha e Silveira (1996) e Tomazelli e Villwock (2000), entende-se, portanto, que este terraço lagunar resultou da progradação da Barreira III a partir da parte leste da Barreira II, localizada em maior altitude. A morfologia deste terraço evidencia um contato suave entre o terraço lagunar da Barreira II e as áreas deprimidas da Barreira IV.

\section{Terraço alúvio-lagunar}

Este terraço guarda semelhanças em relação ao que identificam Tomazelli e Villwock (2000) como superfície de abrasão do Sistema III e ao que indicam Cunha e Silveira (1996) como Planície Alta Atacada.

De cronologia respectiva ao terceiro evento glácio-eustático, pode-se considerar que o terraço alúvio-lagunar apresenta gênese decorrente da alteração do nível de base regional promovido pela regressão marinha na transição da fase interglacial para a glacial, do que resultou a potencialização de processos flúvioerosivos no aprofundamento de talvegues. Disso também se entende a ocorrência de erosão remontante de afluentes do atual Arroio Pelotas, que proporcionaram a erosão e o transporte de materiais do terraço lagunar da Barreira II para serem depositados no terraço e planície de gênese alúvio-lagunar, dado que, de acordo com Cunha e Silveira (1996, p.25), nessa área "a drenagem é efetivada por depressões fósseis da Planície Alta [terraço lagunar da Barreira II]". 
Além de Cunha e Silveira (1996), essa dedução fundamenta-se em Tomazelli e Villwock (2000) quando estes explicam que:

\begin{abstract}
A fase regressiva que se seguiu [ao pico transgressivo do Sistema III- 120 ka] atingiu seu máximo há aproximadamente $17 \mathrm{ka}$. Uma ampla planicie costeira ocupava o que hoje é a plataforma continental e o Sistema Lagunar Patos-Mirim estava transformado numa grande planicie fluvial, área de passagem dos cursos de água que erodindo depósitos antigos aprofundavam seus vales até chegar à linha de costa situada a aproximadamente $120 \mathrm{~m}$ abaixo do atual nivel do mar (TOMAZELLI; VILLWOCK, 2000, p.395).
\end{abstract}

\section{Terraço lagunar (Barreira II)}

A morfologia e litoestratigrafia desta forma de relevo confirmam se tratar do mesmo terraço de abrasão constatado por Tomazelli e Villwock (2000).

Durante a rápida transgressão do Sistema
II, as águas do corpo lagunar [Laguna dos Patos e Lagoa Mirim - Sistema Lagunar Patos-Mirim] avançaram sobre os sedimentos do Sistema Leques Aluviais, retrabalhandoos e esculpindo um terraço de abrasão que se estende por boa parte da margem oeste da planicie costeira. Este terraço, situado entre 18-24 $m$ de altitude, marca a superficie transgressiva deste corpo lagunar (TOMAZELLI; VILLWOCK, 200, p.389).

Em função de marcar a primeira transgressão que se tem vestígios em Pelotas - com pico há $~ 325$ $\mathrm{ka}$ - e não sofrer com intenso retrabalhamento de seus materiais no terceiro e quarto pico transgressivo marinho ( $\sim 120 \mathrm{e} \sim 5 \mathrm{ka}$, respectivamente), os solos desse terraço são melhor desenvolvidos se equiparados aos das formas do Sistema IV.

É correlacionável a maior parte da zona geomorfológica mapeada por Cunha (1996a) sob a denominação de Planície Alta. O terraço lagunar da Barreira II é bastante evidente em alguns locais do centro da cidade de Pelotas (Figura 8).

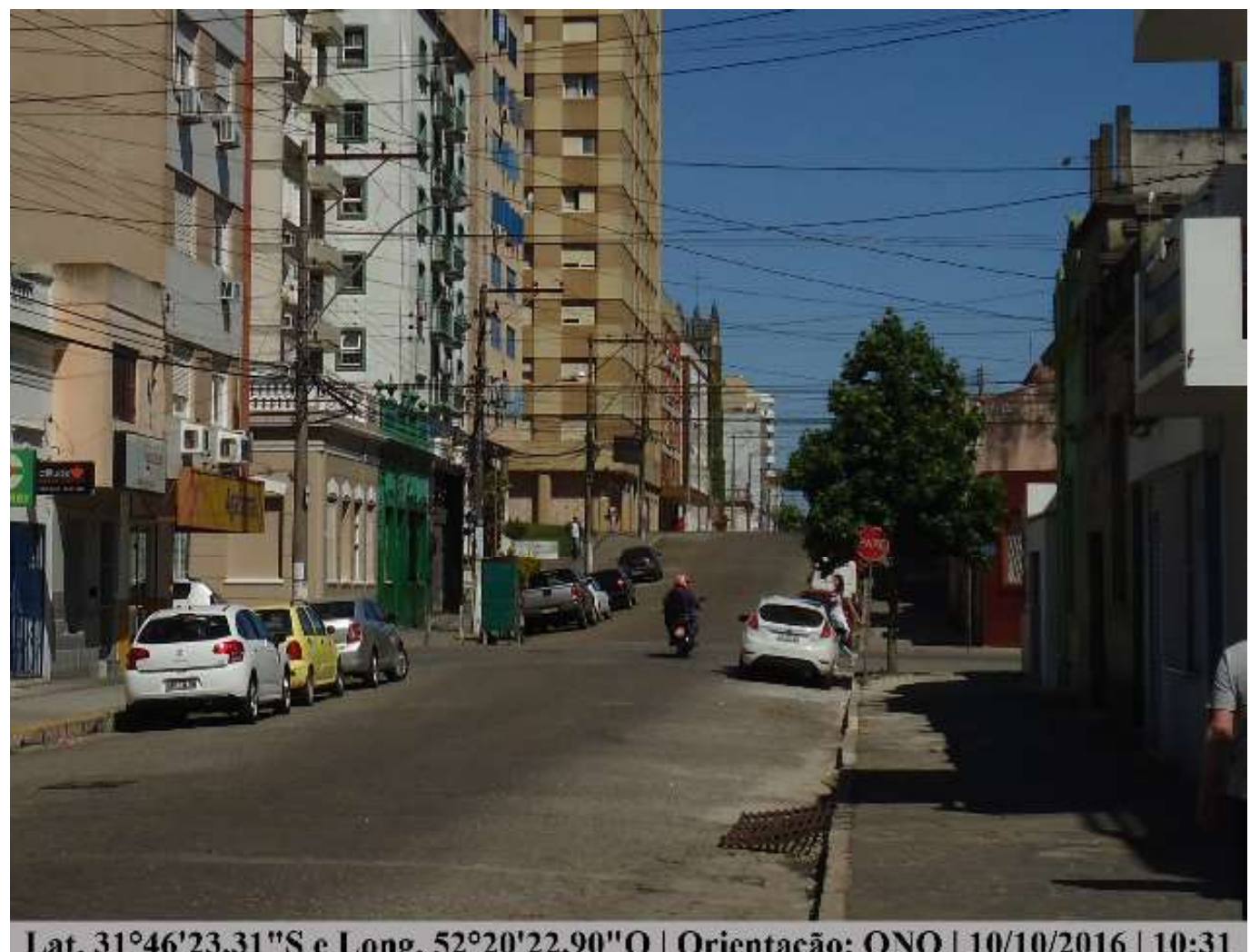

Figura 8 - Transição entre a planície alúvio-lagunar do São Gonçalo ( $1^{\circ}$ Plano $)$ e terraço lagunar da Barreira II $\left(2^{\circ}\right.$ Plano), na R. General Teles, centro da cidade de Pelotas. 


\section{Terraço alúvio-coluvionar}

É correlacionável à Planície Alta mapeada por Cunha (1996a). Em função disso, este terraço apresenta semelhança de solos com o terraço lagunar da Barreira II, porém sua litoestratigrafia destaca-se por ser constituída de alúvio-colúvio (CPRM, 2008, 2016). Conforme Tomazelli e Villwock (2000), a formação desses depósitos é estabelecida por um sistema de leques aluviais alimentados pelo Escudo Sul-Rio-Grandense desde o Terciário superior.

No decorrer do Quaternário, após a individualização das lagoas Patos e Mirim, as fácies distais do sistema deleques passaram aser retrabalhadas pelos agentes hidrodinâmicos do ambiente lagunar. A expressão geomorfológica mais importante deste retrabalhamento foi a formação de terraços escalonados ao longo da rampa deposicional dos leques aluviais. Este terraceamento marca claramente uma resposta às variações de nível dos corpos lagunares como consequência das flutuações quaternárias do nível relativo do mar (TOMAZELLI; VILLWOCK, 2000, p.384).

Para estes autores, as fácies proximais desses leques podem apresentar diamictitos sustentados por lamitos maciços, que possibilitam supor gênese por fluxo de detritos; as fácies médias e distais comumente apresentam fragmentos de arenito e conglomerados de geometria lenticular, que sugerem a migração de formas de leito com provável associação a canais fluviais entrelaçados. Guerra, A. T. e Guerra, A. J. T. (2008, p.154) esclarecem que os conglomerados "constituem prova do abaixamento do nível do mar, ou afundamento de rio" (Figura 9).

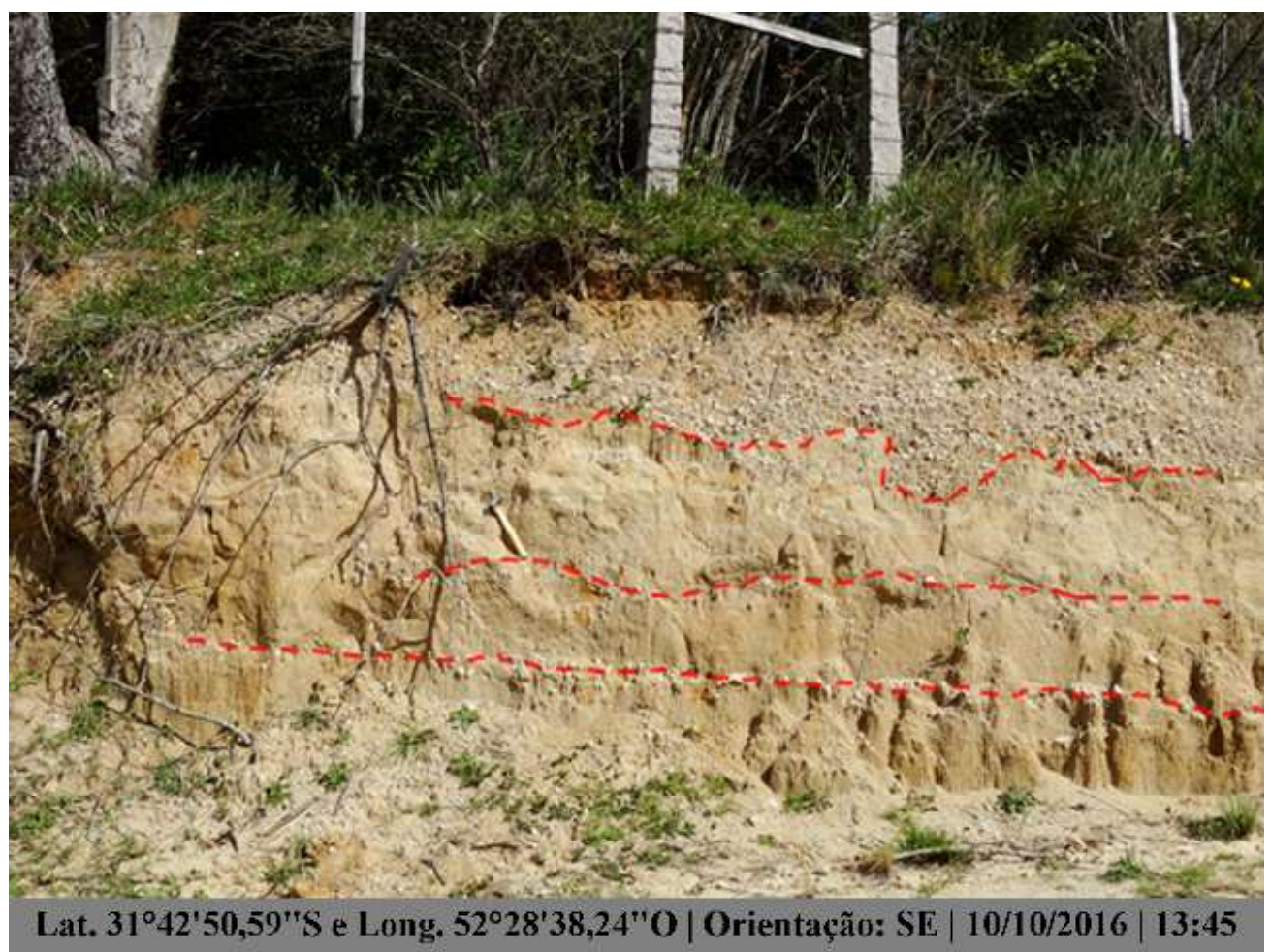

Figura 9-Terraço alúvio-coluvionar: possiveis niveis de base evidenciados no contato (linha tracejada) entre camadas de material exposto em corte de estrada a cerca de $25 \mathrm{~m}$ da margem direita do Arroio Fragata.

\section{Processos ativos em tipos de formas de relevo e impactos ambientais associados}

\section{Área urbana}

Considerando-se os acumulados pluviométricos de eventos climáticos extremos analisados por Hansmann (2013) e Rutz (2015), as áreas urbanizadas sofrem com a recorrência de inundações em locais onde a morfologia original do relevo condiciona a concentração da água pluvial em depressões correspondentes às planícies fluviais que, ora impermeabilizadas, apresentam o aumento do escoamento superficial em virtude do impedimento à infiltração da água no solo. A isso se soma, na região Centro, a retilinização de cursos fluviais 
de parte do canal do Arroio Santa Bárbara e do Arroio Pepino. As obras empreendidas, tanto em um como em outro canal, derivaram da expansão urbana nas margens dos cursos fluviais que, devido às inundações frequentes, demandou artifícios de drenagem para a cidade.

Na planície alúvio-lagunar do Arroio Santa Bárbara, também são registradas morfodinâmicas na área do reservatório de água que abastece Pelotas. Neste reservatório, a alteração de um estado lótico para lêntico da água e a ação dos ventos e das ondas desenvolvem margens de abrasão em que os declives acentuam o efeito da gravidade e o recuo das margens. Os materiais oriundos dessa abrasão, somados a sedimentos transportados por tributários, podem definir feições deposicionais. Há o aumento da carga de fundo e de suspensão, do que pode resultar o assoreamento do reservatório e a diminuição de seu tempo útil (CUNHA, 2009).

$\mathrm{Na}$ área correspondente à planície alúvio-lagunar do São Gonçalo, limitada por descontinuidades de aclives com os terraços, as baixas declividades dos terrenos e a superficialidade do lençol freático dificultam o escoamento pluvial. O lixo carreado para os encanamentos prejudica ainda mais o esgotamento das águas, o que torna frequente os alagamentos nesse compartimento do relevo, densamente urbanizado nas regiões administrativas Centro, Fragata e São Gonçalo. Além disso, tem destaque as intervenções antrópicas na dinâmica fluvial do Arroio Pelotas, mediante aterramento de áreas úmidas, impermeabilização de superfície, supressão de mata ciliar e contenção de erosões em margens côncavas.

A área urbanizada avançou por ambientes paludiais e diminuiu a abrangência espacial das dunas, alterando aquíferos e habitats de reprodução de espécies animais (SELMO \& ASMUS, 2006). Nas dunas, verificam-se processos de erosão eólica e fitoestabilização das areias expostas. Mesmo definidas como uma Área de Preservação Permanente Degradada (PREFEITURA DE PELOTAS, 2008), as dunas continuam sendo impactadas pelo trânsito de veículos e pessoas, bem como por pastoreio, o que prejudica a manutenção da biodiversidade e o resguardo de registros paleontológicos e geológicos.

Em parte da planície alúvio-lagunar do Arroio Fragata, a duplicação da BR-392/471 promove alterações significativas de morfodinâmicas do relevo.
Esta rodovia está situada quase no limite entre a forma de planície alúvio-lagunar e de terraço alúviocoluvionar, constituindo-se como que um dique à influência do Arroio Fragata. Também, observam-se alterações decorrentes de ocupações urbanas em áreas úmidas.

Acerca da forma de planície lacustre e da de pontal, nestas estão situadas a Praia do Laranjal e o Pontal da Barra, respectivamente. Evidenciam-se alterações de morfodinâmicas a partir do aterramento de áreas úmidas, impermeabilização da superfície por construções (moradias e comércios) e alguns arruamentos asfaltados, resultantes da urbanização incoerente à função de áreas úmidas para o sistema lagunar e o fluxo gênico da biodiversidade. No encontro dessas formas de relevo, destaca-se a concentração de vestígios arqueológicos de cerritos de índios (PREFEITURA DE PELOTAS, 2013).

No Barro Duro, em função da descontinuidade de aclive, bastante perceptível entre a lombada e a planície lacustre, processos erosivos são ativados e afeiçoam formas de sulco, ravina e, até mesmo, voçoroca, onde há a remoção da cobertura vegetal. Embora urbanizada, a maior parte dos arruamentos, calçadas e pátios residenciais não estão impermeabilizados - fator positivo para a infiltração da água no solo e a diminuição do escoamento superficial, o que promoveria erosão laminar na lombada e linear na transição da lombada para a planície. Elemento negativo é a existência de esgoto não canalizado e tratado e o descarte inadequado de resíduos sólidos urbanos.

\section{Área rural}

Em consequência do pastoreio às margens de cursos fluviais, verificam-se processos erosivos em caminhos preferenciais de animais. Além disso, em função do pisoteio de animais, pode-se supor o aumento da densidade do solo e, por conseguinte, do escoamento superficial difuso em planícies e terraços.

O desnudamento dos solos e sua exposição direta às chuvas ocorrem em função de práticas agrícolas, da rizicultura, soja e silvicultura, e de obras rodoviárias. Nesse sentido, atenta-se para o fato de que a interrupção das obras de duplicação da BR-116, no trecho Pelotas-Porto Alegre, é hoje o principal motivo para o desenvolvimento de formas de processos atuais. As formas caracterizam-se por sulcos e ravinas, visto que 
em muitos locais a fitoestabilização dos taludes de cortes é ineficiente, e em outros sequer foi iniciada. Ademais, os materiais tecnogênicos utilizados nas obras, sejam por suas características ou técnicas empregadas, parecem não apresentar a devida estabilidade requerida. Os materiais são carreados para as planícies alúviolagunares adjacentes, formando depósitos sedimentares e, devido à redução das competências fluviais nessas seções, há possibilidade de assoreamentos dos canais. Em estradas não pavimentadas, identifica-se a potencialidade para os processos pluvioerosivos às margens das vias e o carreamento ainda maior de sedimentos para os canais fluviais, que podem resultar da falta de canalização adequada para o escoamento da água da chuva e de fitoestabilização de taludes de cortes.

$\mathrm{Na}$ transição entre a planície paludial e o terraço lagunar da Barreira III, o crescimento do aglomerado urbano da Colônia de Pescadores Z-3 altera os processos morfodinâmicos de maneira sensível. De acordo com Delamare et al. (2015) e com observações feitas a campo, as modificações são evidentes tanto em cursos fluviais como na linha de costa lagunar, com destaque para a retilinização e transposição do canal Reasilva (Arroio Sujo), construção de arruamentos e estradas e construção de atracadouros para barcos de pesca (Divinéia I e Divinéia II). Além disso, observam-se aterramentos e construção de molhes que dão acesso aos atracadouros.

Na planície alúvio-lagunar do Arroio Pelotas, identifica-se a alteração de morfodinâmicas decorrentes de construção de estrada de acesso a moradias. Os aterros elevam a altimetria e modificam a declividade da superfície. Como consequência, há a alteração da dinâmica fluvial, em virtude do impedimento do transbordamento marginal da água, quando aumentada a vazão fluvial.

\section{Conclusão}

A análise e mapeamento realizados demonstram que a dinâmica evolutiva da área de influência da Planície Costeira de Pelotas decorre de mudanças morfoclimáticas que repercutiram em quatro principais glácio-eustatismos, sendo três pleistocênicos e um holocênico. Considerando-se que cada avanço marinho definiu uma superfície de abrasão, constatase na litoestratigrafia, bem como nos materiais pedogeneizados, indícios seguros da contemporaneidade entre o arranjo geológico e geomorfológico. Atualmente, a conjuntura ambiental desta área é expressa pela inter-relação de variáveis do meio natural e do meio socioeconômico e cultural, do que resultam alterações de processos geomórficos.

A partir da apreensão dessa realidade, entende-se que este estudo:

- Constitui subsídio à gestão e ao planejamento ambiental por meio da delimitação de compartimentos do relevo que sinalizam restrições à substituição de coberturas por usos da terra.

- Viabiliza a criação de material didático sobre a geomorfologia costeira de Pelotas em virtude de seu ineditismo e, por conseguinte, auxilia a promoção da educação ambiental.

- Proporciona informações para o desenvolvimento de pesquisa científica sobre dinâmicas associadas à tensão socioambiental em planícies costeiras.

- Torna-se mais uma referência geológicogeomorfológica para municípios limítrofes a Pelotas, na influência da Planície Costeira, em virtude da abrangência regional da estrutura do relevo.

Por fim, espera-se que o estudo em questão incentive o desenvolvimento de pesquisas sobre a geomorfologia costeira de Pelotas, a fim de que esta seja melhor apreendida, acerca de suas especificidades, e, portanto, possibilidades, como aporte à reprodução sustentável de atividades humanas.

\section{Agradecimentos}

Agradece-se à Coordenação de Aperfeiçoamento de Pessoal de Nível Superior (CAPES) pela concessão de bolsa de mestrado e à Universidade Federal de Pelotas (UFPel) pela disponibilidade de material e auxílio financeiro, destinados à realização de trabalhos de campo.

\section{Referências Bibliográficas}

AB'SÁBER, A. N. Um conceito de Geomorfologia a serviço das pesquisas sobre o Quaternário. Geomorfologia, n. 18, p. $1-23,1969$.

BARBOZA, E. G. ; ROSA, M. L. C. C. ; AYUP-ZOUAIN, R. N. Cronoestratigrafia da Bacia de Pelotas: uma revisão das sequências deposicionais. GRAVEL, v. 6, n. 1, p. 125-138, 2008. 
BARBOZA E. G. ; ROSA, M. L. C. C ; DILLENBURG, S. R. ; TOMAZELLI, L. J. ; AYUP-ZOUAIN, R. N. (2011). Comportamento regressivo/transgressivo da linha de costa na Bacia de Pelotas durante o Holoceno médio e tardio. In: LÓPEZ, R. A. \& MARCOMINI, S. C. (org.). Problemática de los Ambientes Costeros: Sur de Brasil, Uruguay y Argentina. 1.ed. Ciudad Autónoma de Buenos Aires: Editorial Croquis S.R.L. p. 15-30.

CASSETI, V. Geomorfologia. [S.1.]: [2005]. Disponível em: $<$ http://www.funape.org.br/geomorfologia/>. Acesso em: 23 jun. 2015.

CDC - CENTERS FOR DISEASE CONTROL AND PREVENTION. Shapefiles. Disponível em: $<$ https://wwwn. cdc.gov/epiinfo/html/shapefiles.htm\#SAmerica> Acesso em: 10 mar. 2016

CUNHA, N. G.; SILVEIRA, J. C. Estudo dos solos do município de Pelotas. Pelotas: EMBRAPA/CPACT, Editora UFPEL, 1996. 50p.

CUNHA, N. G. Geomorfologia e Solos - Pelotas. Pelotas: EMBRAPA/CPACT, Editora UFPEL, 1996. Escala 1:100.000.

Solos - Pelotas. Pelotas: EMBRAPA/CPACT, Editora UFPEL, 1996. Escala 1:100.000.

CUNHA, S. B. (2009). Geomorfologia Fluvial. In: GUERRA, A. J. T. \& CUNHA, S. B. (org.). Geomorfologia: Uma Atualização de Bases e Conceitos. Rio de Janeiro: Editora Bertrand Brasil. p. 211-252.

CORREA, I. C. S.; WESCHENFELDER, J.; TOLDO JR, E. E.; BAITELLI, R.; SANTOS-FISCHER, C. B. S. Gênese de um Depósito de Turfa na Plataforma Continental do Rio Grande do Sul-Brasil. Quaternary and Environmental Geosciences, Curitiba, v. 6, n. 2, p. 1-9, 2015.

CPRM - Serviço Geológico do Brasil. Geologia e Recursos Minerais do Estado do Rio Grande do Sul. Porto Alegre, 2008. 1 CD. Escala 1:750.000.

Sistema de Informações de Águas Subterrâneas (SIAGAS). Disponível em: <http://siagasweb.cprm.gov.br/ layout/index.php>. Acesso em: 10 abr. 2016.

DELAMARE, T. O.; SIMON, A. L. H.; SATO, S. E. Dinâmica de uso da terra e alterações na linha de costa lagunar: estudo em uma Colônia de Pescadores de Pelotas, RS, Brasil. Revista de Gestão Costeira Integrada, Lisboa, v. 15, n. 2, p. 237-248, 2015. DOI: http://dx.doi.org/10.5894/rgci543

DEMEK, J.; EMBLETON, C.; GELLERT, J.F. \& VERSTAPPEN, H. T. (Eds.). Manual of detailed geomorphological mapping.
Prague: International Geographical Union - IGU, Commission on Geomorphological Survey and Mapping, 1972. 320p.

DIAS, J. L. ; SAD, A. R. E. ; FONTANA, R. L. ; FEIJÓ, F. J. Bacia de Pelotas. Boletim de Geociências da Petrobrás. v. 8, n. 1, p. 235-245, 1994.

DILLENBURG, S.; HESP, P. Geology and Geomorphology of Holocene Coastal Barriers of Brazil. 1.ed. Berlin: Springer, 2009. 390p.

DUTRA, D. S. Mapeamento geomorfológico da área de influência do Escudo Sul-Rio-Grandense no município de Pelotas/RS. 2016. 139f. Dissertação (Mestrado em Geografia) Programa de Pós-Graduação em Geografia, Instituto de Ciências Humanas, Universidade Federal de Pelotas, Pelotas.

FAVILLA, C. A.; CALDASSO, A. L. S.; RODRIGUES, T. L. N.; WILDNER, W.; BACHI, F. A.; VILLWOCK, J. A.; TOMAZELLI, L. J.; DEHNHARDT, B. A. Mapas Geológicos da Região Costeira do Rio Grande do Sul - Escala 1:250.000. Porto Alegre: CPRM/UFRGS, 2000. (Folha SH.22-Y-D Pelotas).

GUERRA, A. T.; GUERRA, A. J. T. Novo dicionário geológicogeomorfológico. 6.ed. Rio de Janeiro: Editora Bertrand Brasil, 2008. 652p.

HANSMANN, H. Z. Descrição e Caracterização das Principais Enchentes e Alagamentos de Pelotas-RS. 2013. 63f. Trabalho de Conclusão de Curso (Graduação em Engenharia Ambiental e Sanitária), Universidade Federal de Pelotas, Pelotas.

HASENACK, H.; WEBER, E. J. (Orgs.). Base cartográfica vetorial continua do Rio Grande do Sul - escala 1:50.000. Porto Alegre, UFRGS-IB-Centro de Ecologia. 2010. 1 DVDROM (Série Geoprocessamento, 3).

IBGE - Instituto Brasileiro de Geografia e Estatística (2016). Banco de Dados Cidades@. Disponível em: <http://www. cidades.ibge.gov.br/xtras/perfil.php?lang $=\& \operatorname{codmun}=431440$ $\&$ search=rio-grande-do-sul|pelotas $>$. Acesso em: 2 abr. 2016.

(2013). Base Cartográfica Contínua do Brasil na escala de 1:250.000. Disponível em: < https://mapas.ibge.gov.br/ bases-e-referenciais/bases-cartograficas/malhas-digitais.html $>$. Acesso em: 10 dez. 2015.

(2009). Manual Técnico de Geomorfologia. Coordenação de Recursos Naturais e Estudos Ambientais. In: Manuais Técnicos em Geociências. №5. Instituto Brasileiro de Geografia e Estatística. Rio de Janeiro. Disponível em: $<$ https://biblioteca. ibge.gov.br/visualizacao/livros/liv66620.pdf $>$ Acesso em: 19 ago. 2015. 
(2003). Ministério do Planejamento, Orçamento e Gestão. Diretoria de Geociências. Geomorfologia. Folha SH-22Y-D Pelotas. Rio Grande do Sul. Disponível em: <ftp://geoftp. ibge.gov.br/informacoes_ambientais/geomorfologia/mapas/ escala_250_mil/sh22yd_zc_geom.pdf $>$ Acesso em: 7 jul. 2015.

INPE - Instituto Nacional de Pesquisas Espaciais. Projeto TOPODATA - Banco de Dados Geomorfométricos do Brasil. Altitude (Folha 31S525 e 31S54), 2011. Resolução 30m. Disponível em: <http://www.webmapit.com.br/inpe/topodata/>. Acesso em: 22 mai. 2016.

. Imagens do satélite Landsat, instrumento TM5. Brasil, Pelotas. Órbita/Ponto 221/82. Obtidas em: 23 out. 2011, 11 abr. 1985, 01 jun. 1986, 23 jun. 2000. Resolução 90m. Disponível em: <http://www.dgi.inpe.br/CDSR/>. Acesso em: 30 nov. 2015.

MAGAlHÃES, M. O. Opulência e Cultura na Província de São Pedro do Rio Grande do Sul: um estudo sobre a história de Pelotas (1860 - 1890). 1993. 257f. Dissertação (Mestrado em História) - Programa de Pós-Graduação em História, Universidade Federal de Santa Catarina, Florianópolis.

MARTH, J. D.; KOESTER, E.; ARNDT, A. L. Mapa geológicogeomorfológico do município de Pelotas, RS. In: XVII Congresso de Iniciação Científica (CIC)/X Encontro de PósGraduação (ENPOS), 2008, Pelotas. Anais de Ciências Exatas e da Terra. Pelotas: UFPel. 2008. p. 1-5.

MENEGAT, R.; FERNANDES, L. A.D.; KOESTER, E. \& SCHERER, C. M. S. (1998) Porto Alegre antes do homem: evolução geológica. In: MENEGAT, R. (org.). Atlas Ambiental de Porto Alegre. Porto Alegre: UFRGS. p. 11 - 14.

PREFEITURA DE PELOTAS (2013). Plano Ambiental de Pelotas. Pelotas: Secretaria de Qualidade Ambiental, 120p. Disponível em: <http://www.pelotas.rs.gov.br/qualidadeambiental/plano-municipal/arquivos/Plano-Ambiental-dePelotas.pdf>. Acesso em 4 mar. 2016.

(2008). III Plano Diretor de Pelotas. Mapa temático: áreas especiais de interesse do ambiente natural. Pelotas: Secretaria Municipal de Urbanismo. Escala 1:100.000. Disponível em: $<$ http://www.pelotas.com.br/politica_urbana_ ambiental/planejamento_urbano/III_plano_diretor/lei_iii_ plano_diretor/arquivos/U08_AEIAN_IIIPD.pdf $>$. Acesso em: 2 mai. 2016.

ROSA, M. Geografia de Pelotas. Pelotas: UFPel, 1985. 333p.

ROSS, J. L. S. Registro cartográfico dos fatos geomorfológicos e a questão da taxonomia do relevo. Revista do Departamento de Geografia - USP. São Paulo, v. 6, n. 1, p. 17-29, 1992. DOI: http://dx.doi.org/10.7154/RDG.1992.0006.0002

. Geomorfologia: ambiente e planejamento - (Coleção Repensando a Geografia). 9.ed. São Paulo: Editora Contexto, 2014. 89p.

RUTZ, E. C. Análise histórica das enxurradas no município de Pelotas e as consequências da enxurrada de 2009 na bacia hidrográfica do Arroio Quilombo, Pelotas/RS. 2015. 124f. Dissertação (Mestrado em Geografia) - Programa de Pós-Graduação em Geografia, Instituto de Ciências Humanas, Universidade Federal de Pelotas, Pelotas.

SANTOS, H. G.; JACOMINE, P. K. T.; ANJOS, L. H. C.; OLIVEIRA, V. A.; LUMBRERAS, J. F.; COELHO, M. R.; ALMEIDA, J. A.; CUNHA, T. J. F.; OLIVEIRA, J. B. Sistema Brasileiro de Classificação de Solos. Brasília: EMBRAPA, 2013. 353p.

SELMO, F. S. \& ASMUS, M. L. Análise ambiental da ocupação urbana do Pontal da Barra, Praia do Laranjal, Pelotas, RS. Revista Eletrônica: Cadernos de Ecologia Aquática, Rio Grande, v. 1, n. 2, p. 30-37, 2006.

SIMON, A. L. H. A dinâmica de uso da terra e sua interferência na morfohidrografia da bacia do Arroio Santa Bárbara - Pelotas (RS). 2007. 187f. Dissertação (Mestrado em Geografia) - Programa de Pós-Graduação em Geografia, Universidade Estadual Paulista "Júlio de Mesquita Filho".

TESSLER, M. G.; GOYA, S. C. Processos Costeiros Condicionantes do Litoral Brasileiro. Revista do Departamento de Geografia, v. 17, n. 1, p. 11-23, 2005. DOI: http://dx.doi. org/10.7154/RDG.2005.0017.0001

TOMAZELLI, L. J.; VILLWOCK, J. A. (2000). O Cenozóico no Rio Grande do Sul: Geologia da Planície Costeira. In: Holz, M. \& De Ros, L. F. (org.) Geologia do Rio Grande do Sul. Editora CIGO/UFRGS, Porto Alegre, p. 375-406.

TORRES, F. T. P.; NETO, R. M.; MENEZES, S. O. Introdução à Geomorfologia. 1.ed. São Paulo: Editora Cengage Learning, 2013. 336p.

UFRGS-IB-Centro de Ecologia. Mapeamento da cobertura vegetal do Bioma Pampa: Ano-base 2009. Porto Alegre: UFRGSIB-Centro de Ecologia. 2016.

WILDNER, W.; LOPES, R. C. (2010). Evolução Geológica: do Paleoproterozóico ao Recente. In: VIERO, A. C.; SILVA, D. R. A. (org.). Geodiversidade do estado do Rio Grande do Sul. 1.ed. Porto Alegre: Editora CPRM. p. 15-34. 